Syntax Literate: Jurnal Ilmiah Indonesia p-ISSN: 2541-0849

e-ISSN: 2548-1398

Vol. 5, No. 8, Agustus 2020

\title{
ANALISIS PERSPEKTIF KEUANGAN, PELANGGAN, PROSES BISNIS DAN PERTUMBUHAN TERHADAP KINERJA ORGANISASI PADA YAYASAN ACT JAKARTA
}

\section{Pri Pantjaningsih}

Fakultas Ekonomi STIE Manajemen Bisnis Indonesia Jakarta

Email: pripantjaningsih318@gmail.com

\section{Abstract}

This study aims to obtain in-depth information on the application of financial, customer, internal business, and growth perspectives in assessing organizational performance and to obtain how much from the results of data processing each perspective can assess organizational performance. This research uses a descriptive quantitative analysis method. The results of this study: (1) The financial perspective of the Aksi Cepat Tanggap Foundation is generally categorized as good (2) The overall consumer perspective can be categorized as good. (3) The perspective of internal business processes as a whole is categorized as good (4) The perspective of growth and performance learning at the Aksi Cepat Tanggap Foundation can be categorized as good. The results of this study that the performance assessment using the perspective of finance, customers, internal business, and learning \& growth of the Balanced Scorecard method can be concluded that the better for each year.

Keywords: Balanced Scorecard; performance assessment; foundation

\begin{abstract}
Abstrak
Penelitian ini bertujuan untuk memperoleh informasi secara mendalam terhadap penerapan perspektif keuangan, pelanggan, bisnis internal dan pertumbuhan dalam menilai kinerja organisasi serta memperoleh seberapa besar dari hasil olahan data masing masing-masing perspektif dapat menilai kinerja organisasi. Penelitian menggunakan metode analisis deskriptif kuantitatif. Hasil penelitian ini: (1) Perspektif keuangan Yayasan Aksi Cepat Tanggap secara umum dikategorikan baik (2) Perspektif konsumen secara keseluruhan dapat dikategorikan baik. (3) Perspektif proses bisnis internal secara keseluruhan dikategorikan baik (4) Perspektif pertumbuhan dan pembelajaran kinerja Yayasan Aksi Cepat Tanggap dapat dikategorikan baik. Hasil dari penelitian ini bahwa penilaian kinerja dengan menggunakan perspektif keuangan, pelanggan, bisnis internal dan pembelajaran \& pertumbuhan metode Balanced Scorecard dapat disimpulkan semakin baik untuk setiap tahunnya.
\end{abstract}

Kata kunci: Balanced Scorecard; penilaian kinerja; yayasan 


\section{Pendahuluan}

Salah satu organisasi nirlaba profesional yang memfokuskan kerja-kerja kemanusiaan pada penanggulangan bencana mulai fase darurat sampai dengan fase pemulihan paska bencana yakni Yayasan Aksi Cepat Tanggap (ACT). Pada umumnya sumber dana yang digunakan untuk menjalankan kegiatan organisasi ACT yakni donasi yang berasal dari sumbangan atau donatur dari orang-orang yang ingin membantu sesamanya. Donasi tersebut dapat berupa dana kemanusiaan atau sosial, sedekah dan wakaf (Setianto, 2020).

Berdasarkan hasil penelitian yang diselenggarakan oleh UIN Syarif Hidayatullah Jakarta bekerjasama dengan Ford Foundation tentang potensi zakat, infaq dan shadaqah belum termasuk Wakaf (selanjutnya disingkat ZISWaf) disimpulkan bahwa potensi ZIS diluar Wakaf di Indonesia sebesar 19,3 triliun. Penelitian dengan topik yang sama diselenggarakan oleh PIRAC mencatat bahwa potensi dana ZISWaf sebesar 20 triliun. (https://www.rumahzakat.org/dahsyatnya-potensi-ziswaf-di-indonesia/). Dengan begitu besarnya potensi dana publik yakni ZISWaf maka dibutuhkan lembaga pengelola dana publik ZISWaf professional yang mampu mengahadapi persaingan bisnis.

ACT merupakan salah satu lembaga pengelola dana publik, begitu besar potensi dana publik maka dibutuhkan suatu pengukuran kinerja setiap periode. Kinerja dalam suatu periode tertentu dapat dijadikan acuan untuk mengukur tingkat keberhasilan organisasi. Oleh Karena itu, sistem kinerja yang sesuai dan cocok untuk organisasi sangat diperlukan agar suatu organisasi mampu bersaing dan berkembang.

Dari hasil uraian tersebut, dapat diartikan penelitian ini bertujuan agar dapat memperoleh hasil kinerja ACT pada suatu periode tertentu sebagai alat ukur untuk mengukur tingkat keberhasilan. Dan penelitian ini juga bermanfaat bagi donatur dan juga masyarakat agar dapat digunakan sebagai alat control ataupun evaluasi pada kinerja Lembaga ACT, serta bagi ilmu pengetahuan dapat dijadikan tolak ukur sebagai ukuran di periode tertentu.

Pengukuran kinerja menjadi salah satu faktor yang sangat penting bagi organisasi. Sistem pengukuran kinerja dapat menjadi alat pengendalian organisasi karena pengukuran kinerja dibuat dengan menetapkan reward dan punishment system. Sistem pengukuran kinerja tradisional merupakan salah satu cara yang umumnya digunakan oleh manajemen tradisional untuk mengukur kinerja (Pramadhany \& Rahardjo, 2011). Pengukuran kinerja secara tradisonal lebih menekankan kepada aspek keuangan, Karena lebih mudah diterapkan sehingga tolok ukur kinerja perusahaan diukur berkaitan dengan aspek keuangan saja. Sistem ini lazim dilakukan dan mempunyai beberapa kelebihan, akan tetapi karena hanya mentikberatkan pada aspek keuangan tentunya menimbulkan adanya kelemahan.

Ukuran kinerja yang baik tidak hanya mampu meningkatkan kinerja organisasi namun juga membawa perubahan positif dalam memenuhi harapan publik atas pelayanan yang diberikan (Fitriyani, 2014). Untuk meningkatkan kinerja organisasi, maka diperlukan suatu sistem berbasis kinerja, kinerja yang baik harus mempunyai sistem pengukuran kinerja yang andal dan berkualitas, sehingga diperlukan penggunaan 
ukuran kinerja yang tidak hanya mengandalkan aspek keuangan saja tetapi juga memperhatikan aspek-aspek non-keuangan. Ada banyak hal yang perlu diperhatikan dalam peningkatan kinerja perusahaan di antaranya peningkatan kualitas sumber daya manusia, peningkatan kualitas pelayanan yang diberikan, peningkatan kualitas manajemen dan peningkatan efisiensi (Nurhayati, 2018). Indikator perusahaan telah mencapai tujuan, visi dan misi biasanya dapat dilihat dari hasil kinerja dan nilai pasar perusahaan (Wijaya, 2012).

Balanced Scorecard merupakan alat untuk mengimplementasikan strategi, selain itu dapat menyelaraskan berbagai fungsi (divisi, departemen, seksi) agar segala keputusan dan kegiatannya di dalam masing-masing fungsi tersebut dapat dimobilisasikan untuk mencapai tujuan perusahaan. Tujuan dan tolak ukur dikembangkan untuk setiap 4 (empat) perspektif yaitu: perspektif keuangan, perspektif pelanggan, perspektif proses usaha dan perspektif pembelajaran dan pertumbuhan (Alimudin, 2017). Balanced scorecard digunakan untuk membantu perusahaan dalam merumuskan dan merencanakan strategi yang tepat untuk mengembangkan usaha tersebut dengan tidak melupakan kapasitas dari perusahaan itu sendiri (Aulia \& Ikhwana, 2012).

Tabel 1 Operasional Variabel

\begin{tabular}{|c|c|c|c|}
\hline Variabel & Dimensi & Indikator & Skala \\
\hline $\begin{array}{l}\text { Variabel (X) Perspektif } \\
\text { Keuangan : rasio yang } \\
\text { digunakan untuk mengukur } \\
\text { kinerja keuangan dengan } \\
\text { rumus rasio efektivitas } \\
\text { metode value for money } \\
\text { (Hadiyati, 2014). }\end{array}$ & $\begin{array}{l}\text { Realisasi perolehan } \\
\text { donasi 2016-2018 } \\
\text { Target penerimaan } \\
\text { donasi 2016-2018 }\end{array}$ & $\begin{array}{l}\text { Rasio Efektivitas per } \\
\text { tahun: Realisasi } \\
\text { Penerimaan donasi } \mathrm{x} \\
\text { 100\% Target } \\
\text { penerimaan donasi }\end{array}$ & Rasio \\
\hline \multirow{7}{*}{$\begin{array}{l}\text { Perspektif pelanggan: rasio } \\
\text { yang digunakan untuk } \\
\text { mengukur kepuasan } \\
\text { pelanggan terhadap pelayanan } \\
\text { organisasi (Hadiyati, 2014). }\end{array}$} & $\begin{array}{l}\text { Rasio Akuisisi donatur } \\
\text { 2016-2018 }\end{array}$ & $\begin{array}{l}\text { Rasio akuisisi donatur } \\
\text { : jumlah donatur baru } \\
\text { X 100\% total donatur }\end{array}$ & Rasio \\
\hline & $\begin{array}{l}\text { Rasio retensi donatur } \\
2016-2018\end{array}$ & $\begin{array}{l}\text { Rasio retensi donatur: } \\
\text { jumlah donatur lama } \\
\text { dalam } 1 \text { periode } \mathrm{x} \\
100 \% \text { total jumlah } \\
\text { donatur }\end{array}$ & Rasio \\
\hline & \multirow{5}{*}{$\begin{array}{l}\text { Tingkat Kepuasan } \\
\text { donatur } 2018\end{array}$} & a. Wujud fisik & \multirow{5}{*}{ Liker } \\
\hline & & b. Keandalan & \\
\hline & & c. Daya tanggap & \\
\hline & & d. Jaminan & \\
\hline & & e. Empati & \\
\hline $\begin{array}{l}\text { Perspektif Bisnis internal: } \\
\text { perspektif yang digunakan } \\
\text { untuk mengukur keunggulan } \\
\text { organisasi melalui perbaikan } \\
\text { proses internal organisasi. }\end{array}$ & $\begin{array}{l}\text { Rasio Retensisi } \\
\text { karyawan 2016-2018 }\end{array}$ & $\begin{array}{l}\text { Rasio retensisi } \\
\text { karyawan: jumlah } \\
\text { karyawan keluar per } \\
\text { periode x } 100 \% \\
\text { jumlah total }\end{array}$ & Rasio \\
\hline
\end{tabular}




\begin{tabular}{|c|c|c|c|}
\hline & $\begin{array}{l}\text { Rasio Produktivitas } \\
\text { karyawan 2016-2018 }\end{array}$ & $\begin{array}{l}\text { Rasio produktivitas } \\
\text { karyawan: peningkatan } \\
\text { penerimaan donasi x } \\
100 \% \text { jumlah total } \\
\text { karyawan }\end{array}$ & Rasio \\
\hline & \multirow{4}{*}{$\begin{array}{c}\text { Tingkat keberhasilan } \\
\text { organisasi dalam } \\
\text { melakukan perbaikan } \\
\text { dan menambah nilai } \\
\text { bagi pelanggan dan } \\
\text { stakeholders }\end{array}$} & a. Motivasi & Likert \\
\hline & & $\begin{array}{l}\text { b. Kesempatan } \\
\text { mengembangkan diri }\end{array}$ & Likert \\
\hline & & c. Inovasi & Likert \\
\hline & & $\begin{array}{l}\text { d. Suasana dalam } \\
\text { bekerja }\end{array}$ & Likert \\
\hline \multirow{9}{*}{$\begin{array}{c}\text { Variabel (Y) Kinerja : Kinerja } \\
\text { merupakan hasil dari evaluasi } \\
\text { terhadap pekerjaan yang telah } \\
\text { selesai dilakukan, hasil dari } \\
\text { pekerjaan tersebut } \\
\text { dibandingkan dengan kriteria } \\
\text { yang telah ditetapkan } \\
\text { bersama. Pengukuran kinerja } \\
\text { organisasi dapat dilakukan } \\
\text { dengan penggunakan laporan } \\
\text { internal data organisasi dan } \\
\text { penyebaran quesioner sebagai } \\
\text { dasar untuk melakukan } \\
\text { pengukuran kinerja. } \\
\text { Herwanto (2018) }\end{array}$} & Rasio Efektivitas & \multirow{9}{*}{$\begin{array}{c}\text { Laporan hasil } \\
\text { penilaian kinerja } \\
\text { organisasi berdasarkan } \\
\text { perspektif keuangan, } \\
\text { perspektif pelanggan, } \\
\text { perspektif bisnis } \\
\text { internal dan perspektif } \\
\text { pertumbuhan dan } \\
\text { pembelajaran }\end{array}$} & Rasio \\
\hline & Rasio Akuisisi donatur & & Rasio \\
\hline & Rasio retensi donatur & & Rasio \\
\hline & $\begin{array}{l}\text { Tingkat kepuasan } \\
\text { donatur dan penerima }\end{array}$ & & Likert \\
\hline & Rasio inovasi & & Rasio \\
\hline & Rasio proses operasi & & Rasio \\
\hline & $\begin{array}{l}\text { Rasio Retensisi } \\
\text { karyawan }\end{array}$ & & Rasio \\
\hline & $\begin{array}{l}\text { Rasio produktivitas } \\
\text { karyawan }\end{array}$ & & Rasio \\
\hline & $\begin{array}{l}\text { Tingkat kepuasan } \\
\text { karyawan }\end{array}$ & & Likert \\
\hline
\end{tabular}




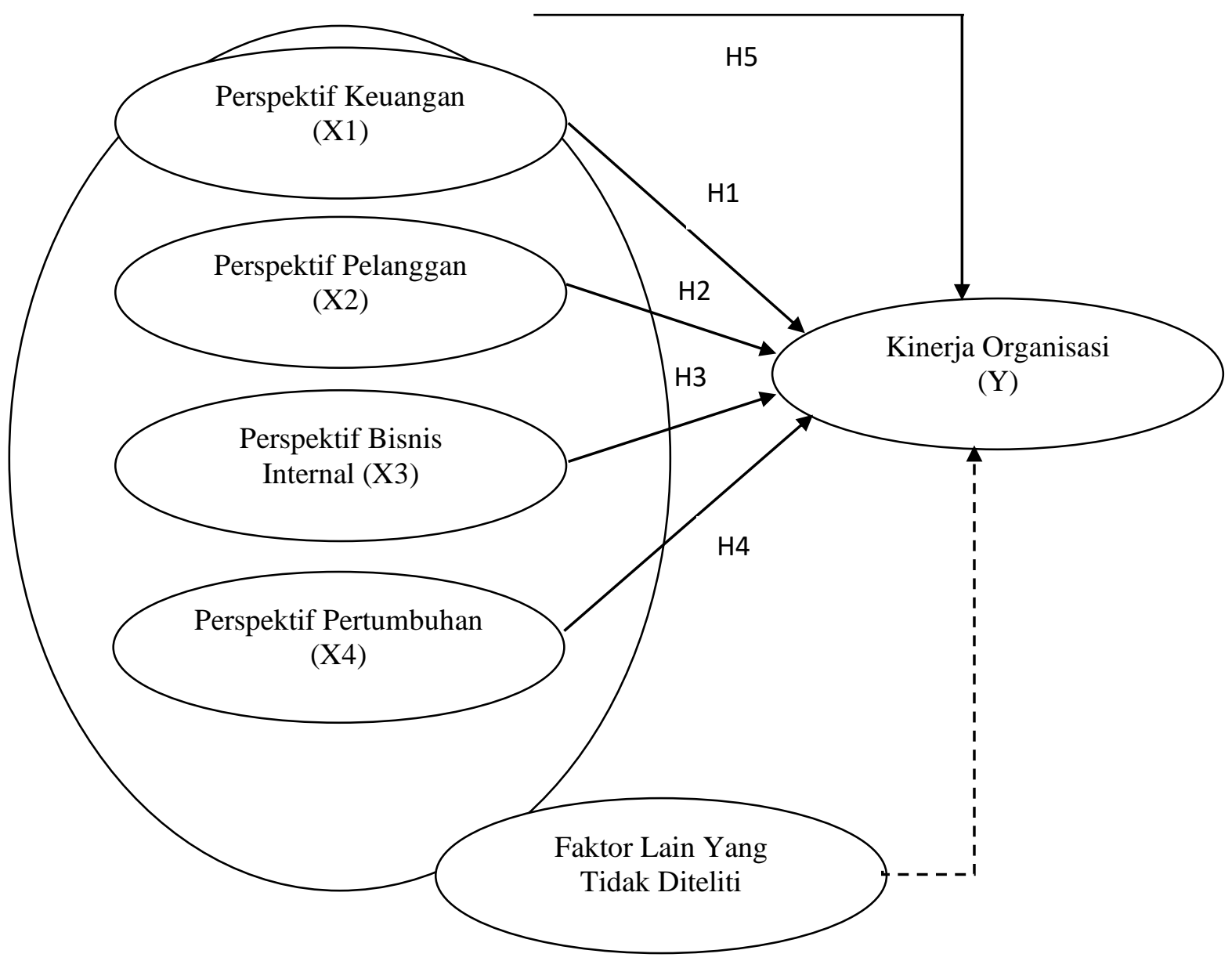

Hipotesis

\section{Gambar 1 Model Penelitian}

H0 : Diduga perspektif keuangan, pelanggan, bisnis internal dan pertumbuhan \& pembelajaran tidak dapat menilai kinerja organisasi

H1 : Diduga perspektif keuangan dalam metode Balanced Scorecard dapat menilai kinerja organisasi

H2 : Diduga perspektif pelanggan dalam metode Balanced Scorecard dapat menilai kinerja organisasi

H3 : Diduga perspektif bisnis internal dalam metode Balanced Scorecard dapat menilai kinerja organisasi

H4 : Diduga perspektif pertumbuhan dan pembelajaran dalam metode Balanced Scorecard dapat menilai kinerja organisasi

H5 : Diduga hasil olahan data terhadap penerapan perspektif keuangan, pelanggan, bisnis internal dan pertumbuhan dapat menilai kinerja organisasi. 


\section{Metode Penelitian}

Sebelum dilakukan perhitungan dan pengolahan dengan menggunakan alat analisis, maka semua instrumen penelitian diuji terlebih dahulu untuk mengetahui apakah instrumen tersebut valid dan reliabel. Pengujian instrumen dilakukan dengan menggunakan :

1. Uji Validitas

2. Reliabilitas

Analisis data yang digunakan dengan cara mengukur masing-masing perspektif yang terdiri dari perspektif keuangan, bisnis internal, penggan serta pertumbuhan. Dalam penelitian ini analisis data yang dilakukan untuk mengetahui penilaian kinerja dengan menggunakan Balanced Scorecard, yakni dengan tahapan:

a. Mengukur kinerja dari perspektif keuangan

$$
\text { Rumus }=\frac{\text { Realisasi Perolehan donasi }}{\text { Target Penerimaan donasi }} \times 100 \%
$$

b. Mengukur kinerja dari perspektif pelanggan

c. Kemampuan Pemerolehan Donatur (Akuisisi Donatur):

Mengukur tingkat kemampuan lembaga dalam mendapatkan pelanggan (donatur) baru (Pramadhany \& Rahardjo, 2011).

Rumus $=\underline{\text { Jumlah Donatur baru }} \times 100 \%$

Total Donatur

d. Kemampuan Mempertahankan Donatur (Retensisi Donatur):

Mengukur tingkat dimana lembaga dapat mempertahankan hubungan dengan pelanggan dalam hal ini donatur (Pramadhany \& Rahardjo, 2011)

Rumus $=\underline{\text { Jumlah Donatur non aktif dalam } 1 \text { periode }} \times 100 \%$

Total jumlah Donatur

e. Tingkat kepuasan Donatur

$\mathrm{IKK}=\mathrm{PP}$

Dimana:

IKK = indeks kepuasan karyawan

$\mathrm{PP}=$ perceived performance

IK Maks $=\mathrm{R} \times \mathrm{PP} \times$ EX maks

IK Min $\quad=\mathrm{R} \times \mathrm{PP} \times \mathrm{EX}$ min

Interval $=(\mathrm{IK}$ maks $-\mathrm{IK} \min )$

Dimana:

$\mathrm{PP}=$ Banyak pertanyaan

$\mathrm{R}=$ Jumlah Responden

EX min = skor minimal yang diberikan

EX maks = skor maksimal yang diberikan

f. Mengukur kinerja dari perspektif bisnis internal

1) Inovasi,

Inovasi $=\quad$ Jumlah perolehan program baru $\times 100 \%$

Target program baru 
Pri Panjaningsih

2) Proses Operasi,

Operasi $=\underline{\text { Jumlah pendapatan programx }}$ 100\%

Target program

g. Perspektif pembelajaran dan pertumbuhan

Adapun pengukurannya sebagai berikut:

1) Retensi Karyawan

Rumus $=\underline{\text { Jumlah karyawan keluar per periode }} \times 100 \%$

Jumlah total karyawan

2) Produktivitas Karyawan

Rumus $=\underline{\text { Peningkatan penerimaan donasi }} \times 100 \%$

Jumlah total karyawan

3) Peningkatan kepuasan karyawan, sebagai berikut:

$\mathrm{IKK}=\mathrm{PP}$

Dimana :

IKK = indeks kepuasan karyawan

$\mathrm{PP} \quad=$ perceived performance

$\begin{array}{ll}\text { IK Maks } & =\mathrm{R} \times \mathrm{PP} \times \mathrm{EX} \text { maks } \\ \text { IK Min } & =\mathrm{R} \times \mathrm{PP} \times \mathrm{EX} \text { min } \\ \text { Interval } & =(\text { IK maks }- \text { IK min }) \\ \text { Dimana: } & =\text { Banyak pertanyaan } \\ \text { PP } & =\text { Jumlah Responden } \\ \mathrm{R} & =\text { skor minimal yang diberikan } \\ \text { EX min } & =\text { skor maksimal yang diberikan }\end{array}$

5. Penilaian Kinerja Berdasarkan Balanced Scorecard

Tabel 2 Rating Scale

\begin{tabular}{cl}
\hline Rating Scale Skor & Nilai \\
\hline-1 & Kurang \\
\hline 0 & Cukup \\
\hline 1 & Baik
\end{tabular}

Sumber: (Radithya \& Tin, 2011)

Setelah menentukan rating scale, selanjutnya adalah membuat ukuran kinerja berisi indikator-indikator yang akan digunakan sebagai dasar pemberian skor. Ukuran kinerja dapat dilihat pada tabel berikut ini: 
Analisis Perspektif Keuangan, Pelanggan, Proses Bisnis dan Pertumbuhan dapat Menilai Kinerja Organisasi

Tabel 3 Ukuran Kinerja

\begin{tabular}{|c|c|c|c|c|}
\hline \multirow[t]{2}{*}{ Perspektif } & \multirow[t]{2}{*}{ Sasaran Strategik } & \multicolumn{2}{|c|}{ Ukuran } & \multirow[t]{2}{*}{ Skor } \\
\hline & & Hasil & Pemacu Kinerja & \\
\hline \multirow[t]{7}{*}{ Keuangan } & Rasio Ekonomi & Penurunan & Revenue mix & 1 \\
\hline & Rasio Efisiensi & biaya & Cycle & 1 \\
\hline & Rasio Efektivitas & Pertumbuhan & effectiveness & 1 \\
\hline & & Pendapatan & & \\
\hline & & Peningkatan & & \\
\hline & & efisiensi & & \\
\hline & & Keuangan & & \\
\hline \multirow[t]{7}{*}{ Pelanggan } & Meningkatnya & Kepuasan & a. Bertambahnya & 1 \\
\hline & kepercayaan & Pelanggan & custumer baru & 1 \\
\hline & pelanggan & Retensi dan & b.Depth of & 1 \\
\hline & & Akuisisi & relationship & \\
\hline & & Pelanggan & c.Berkurangnya & \\
\hline & & Profitabilitas & keluhan & \\
\hline & & Pelanggan & & \\
\hline \multirow[t]{3}{*}{ Bisnis Internal } & Meningkatnya & Inovasi & Efisiensi & 1 \\
\hline & proses layanan & Tingkat & Pelayanan & 1 \\
\hline & kepada donator & pelayanan & & \\
\hline \multirow{6}{*}{$\begin{array}{l}\text { Pembelajara } \\
\text { n dan } \\
\text { Pertumbuha } \\
\text { n }\end{array}$} & Meningkatnya & Retensi dan & a.Karyawan & 1 \\
\hline & kapabilitas karyawan & Kepuasan & keluar & \\
\hline & Meningkatnya & Karyawan & berkurang & \\
\hline & komitmen & Pelatihan & b.Karyawan & 1 \\
\hline & karyawan & Karyawan & mengikuti & \\
\hline & & & latihan & 1 \\
\hline TOTAL & & & & 10 \\
\hline
\end{tabular}

Sumber : (Radithya \& Tin, 2011)

\section{Hasil dan Pembahasan}

\section{A. Hasil Penelitian}

1. Uji Instrumen

a. Uji Validitas perspektif pelanggan

Untuk persepektif pelanggan terdiri dari 15 butir pertanyaan dan pengujian di lakukan terhadap 104 responden. 
Tabel 4 Hasil Pengujian Validitas Kuesioner Kepuasan Pelanggan

\begin{tabular}{cccc}
\hline $\begin{array}{c}\text { Item } \\
\mathrm{N}=104\end{array}$ & $\begin{array}{c}\text { Hitung } \\
(\mathrm{r})\end{array}$ & $\begin{array}{c}\text { Tabel }(\mathrm{r})=0.195 \\
\text { Signifikan }=0.05 \\
\mathrm{dk}=\mathrm{n}-2\end{array}$ & Hasil \\
\hline 1 & 0.732 & 0.195 & Valid \\
\hline 2 & 0.732 & 0.195 & Valid \\
\hline 3 & 0.549 & 0.195 & Valid \\
\hline 4 & 0.613 & 0.195 & Valid \\
\hline 5 & 0.502 & 0.195 & Valid \\
\hline 6 & 0.465 & 0.195 & Valid \\
\hline 7 & 0.668 & 0.195 & Valid \\
\hline 8 & 0.365 & 0.195 & Valid \\
\hline 9 & 0.521 & 0.195 & Valid \\
\hline 10 & 0.531 & 0.195 & Valid \\
\hline 11 & 0.815 & 0.195 & Valid \\
\hline 12 & 0.488 & 0.195 & Valid \\
\hline 13 & 0.687 & 0.195 & Valid \\
\hline 14 & 0.736 & 0.195 & Valid \\
\hline 15 & 0.705 & 0.195 & Valid \\
\hline
\end{tabular}

Sumber: Data diolah 2020

Hasil uji validitas: $r$ hitung $>r$ tabel yaitu $0.195(\alpha=0.05)$ Dari hasil uji validitas pada table 4.8 dapat dilihat bahwa semua pertanyaan valid, terlihat dari $\mathrm{r}$ hitung lebih besar dari $\mathrm{r}$ tabel, jadi dapat diartikan bahwa pertanyaan mampu mengungkapkan sesuatu yang di ukur oleh kuesioner.

b. Uji Validitas perspektif bisnis internal

Untuk persepektif bisnis internal terdiri dari 9 butir pertanyaan dan pengujian di lakukan terhadap 218 responden.

Tabel 5 Hasil Pengujian Validitas bisnis internal

\begin{tabular}{cccc}
\hline $\begin{array}{c}\text { Item } \\
\mathrm{N}=218\end{array}$ & $\begin{array}{c}\text { Hitung } \\
(\mathrm{r})\end{array}$ & $\begin{array}{c}\text { Tabel (r) }=0.138 \\
\text { Signifikan }=0.05 \\
\text { dk }=\mathrm{n}-2\end{array}$ & Hasil \\
\hline 1 & 0.702 & 0.138 & Valid \\
\hline 2 & 0.642 & 0.138 & Valid \\
\hline 3 & 0.264 & 0.138 & Valid \\
\hline 4 & 0.593 & 0.138 & Valid \\
\hline 5 & 0.654 & 0.138 & Valid \\
\hline 6 & 0.695 & 0.138 & Valid \\
\hline 7 & 0.539 & 0.138 & Valid \\
\hline 8 & 0.619 & 0.138 & Valid \\
\hline 9 & 0.582 & 0.138 & Valid \\
\hline
\end{tabular}

Sumber: Data diolah 2020

Hasil uji validitas: $r$ hitung $>r$ tabel yaitu $0.138(\alpha=0.05)$, Dari hasil uji validitas pada Tabel 5 dapat dilihat bahwa semua pertanyaan valid, terlihat dari $r$ hitung lebih besar dari $r$ tabel, jadi dapat diartikan bahwa pertanyaan mampu mengungkapkan sesuatu yang di ukur oleh kuesioner. 
Analisis Perspektif Keuangan, Pelanggan, Proses Bisnis dan Pertumbuhan dapat Menilai Kinerja Organisasi

c. Uji Validitas perspektif pembelajaran dan pertumbuhan

Untuk persepektif pembelajaran dan pertumbuhan terdiri dari 8 butir pertanyaan dan pengujian di lakukan terhadap 218 responden.

Tabel 6 Hasil Pengujian Validitas Persepektif Pembelajaran dan pertumbuhan

\begin{tabular}{cccc}
\hline $\begin{array}{c}\text { Item } \\
\mathrm{N}=218\end{array}$ & $\begin{array}{c}\text { Hitung } \\
(\mathrm{r})\end{array}$ & $\begin{array}{c}\text { Tabel }(\mathrm{r})=0.138 \\
\text { Signifikan }=0.05 \\
\mathrm{dk}=\mathrm{n}-2\end{array}$ & Hasil \\
\hline 1 & 0.647 & 0.138 & Valid \\
\hline 2 & 0.724 & 0.138 & Valid \\
\hline 3 & 0.937 & 0.138 & Valid \\
\hline 4 & 0.844 & 0.138 & Valid \\
\hline 5 & 0.882 & 0.138 & Valid \\
\hline 6 & 0.843 & 0.138 & Valid \\
\hline 7 & 0.875 & 0.138 & Valid \\
\hline 8 & 0.628 & 0.138 & Valid \\
\hline
\end{tabular}

Sumber: Data diolah 2020

Hasil uji validitas: $r$ hitung $>r$ tabel yaitu $0.138(\alpha=0.05)$, Dari hasil uji validitas Tabel 6 dapat dilihat bahwa semua pertanyaan valid, terlihat dari $r$ hitung lebih besar dari $r$ tabel, jadi dapat diartikan bahwa pertanyaan mampu mengungkapkan sesuatu yang di ukur oleh kuesioner.

2. Reliabilitas

Pengujian reabilitas dilakukan untuk mengetahui sejauh mana suatu alat ukur dapat di percaya atau dapat di andalkan. Reliabilitas suatu konstruk variabel dikatakan baik jika memiliki nilai Cronbanch's Alpha lebih dari 0.700 (Ghozali \& Latan, 2015).

Tabel 7 Hasil Uji Reliabilitas

\begin{tabular}{clcl}
\hline \multirow{2}{*}{ No } & \multicolumn{1}{c}{ Persepektif } & $\begin{array}{c}\text { Cronbanch's } \\
\text { Alpha }\end{array}$ & Hasil \\
\hline 1 & Pelanggan & 0.912 & Reliabel \\
\hline 2 & Bisnis Internal & 0,814 & Reliabel \\
\hline 3 & Pembelajaran dan pertumbuhan & 0,782 & Reliabel \\
\hline
\end{tabular}

Sumber : Data diolah 2020

3. Perspektif Keuangan

Rasio Efektivitas

Efektivitas berkenaan dengan apakah suatu alternatif mencapai hasil (akibat) yang diharapkan, atau mencapai tujuan dari diadakan tindakan.Sehingga ukuran efektivitas dapat diartikan sebagai suatu standar akan terpenuhinya mengenai sasaran dan tujuan yang akan dicapai.

Rasio Efektivitas $=\underline{\text { Realisasi perolehan donasi }} \times 100 \%$

Target perolehan donasi 
Tabel 8 Rasio Efektivitas Aksi Cepat Tanggap

\begin{tabular}{cccc}
\hline Tahun & $\begin{array}{c}\text { Realisasi Perolehan } \\
\text { Donasi }\end{array}$ & $\begin{array}{c}\text { Target Perolehan } \\
\text { Donasi }\end{array}$ & $\begin{array}{c}\text { Rasio } \\
\text { Efektivitas }\end{array}$ \\
\hline 2016 & Rp.146.000.000.000 & 186.000 .000 .000 & $78,80 \%$ \\
\hline 2017 & Rp.308.000.000.000 & 300.000 .000 .000 & $102,70 \%$ \\
\hline 2018 & Rp.616.000.000.000 & 664.000 .000 .000 & $92,98 \%$ \\
\hline
\end{tabular}

Sumber: Laporan Keuangan Aksi Cepat Tanggap

Berdasarkan Tabel 8 diatas menunjukkan bahwa, realisasi pendapatan memang menunjukkan adanya peningkatan dari tahun ke tahun. Hal ini menunjukkan Aksi Cepat Tanggap terus meningkatkan baik kualitas maupun kuantitas dari program yang ditawarkan agar dapat semakin menarik minat masyarakat untuk berdonasi ke Aksi Cepat Tanggap.

4. Perspektif Pelanggan

a. Kemampuan Pemerolehan Donatur (Akuisisi Donatur), dengan rumus sebagai berikut:

Akuisisi Donatur $=\underline{\text { Jumlah Donatur Baru }} \times 100 \%$

Total Donatur

Tabel 9 Akuisisi Donatur Baru

\begin{tabular}{cccc}
\hline Tahun & Donatur Baru & Jumlah Donatur & Akuisisi \\
\hline 2016 & 46.799 & 150.598 & $31,07 \%$ \\
\hline 2017 & 68.740 & 219.338 & $31,33 \%$ \\
\hline 2018 & 80.903 & 300,241 & $26,94 \%$ \\
\hline
\end{tabular}

Sumber : Data donatur Aksi Cepat Tanggap

Tabel 9 menunjukkan bahwa Aksi Cepat Tanggap pada tahun 20162018 selalu ada pertambahan donatur baru dari tahun ke tahun. Dari tahun 2016 ke tahun 2017 jumlah donatur baru yang bertambah ada 219.338 donatur. Dari tahun 2017 ke tahun 2018 jumlah donatur baru yang bertambah ada 300.241 donatur.

b. Kemampuan mempertahankan Donatur (Retensi Donatur)

Retensi Donatur $=\underline{\text { Jumlah Donatur Lama dalam } 1 \text { periode }} \times 100 \%$

Total Jumlah Donatur

Tabel 10 Retensi Donatur Aksi Cepat Tangap

\begin{tabular}{cccc}
\hline Tahun & Donatur Lama & Jumlah Donatur & Retensi Donatur \\
\hline 2016 & 64.668 & 150.598 & $42,94 \%$ \\
\hline 2017 & 92.379 & 219.338 & $42,11 \%$ \\
\hline 2018 & 80.873 & 300,241 & $26,93 \%$ \\
\hline
\end{tabular}

Sumber : Data Donatur Aksi Cepat Tangap

Tabel 10 menunjukkan bahwa Aksi Cepat Tanggap pada tahun 2017 mengalami peningkatan jumlah donatur lama, dan mengalami penurunan di tahun 2018. Dari tahun 2016 ke tahun 2017 jumlah donatur lama meningkat sejumlah 27.711 donatur. Dari tahun 2017 ke tahun 2018 jumlah donatur lama menurun sejumlah 11.506 donatur. 
Analisis Perspektif Keuangan, Pelanggan, Proses Bisnis dan Pertumbuhan dapat Menilai Kinerja Organisasi

c. Tingkat Kepuasan Donatur

Analisis tingkat kepuasan donatur Aksi Cepat Tanggap

Tabel 11 Hasil kuesioner tingkat kepuasan donatur

\begin{tabular}{|c|c|c|c|c|c|c|}
\hline \multirow{2}{*}{ Indikator } & \multirow{2}{*}{ Pernyataan kuesioner } & \multicolumn{5}{|c|}{ Jumlah responden } \\
\hline & & SS & $\mathrm{S}$ & $\mathrm{R}$ & TS & STS \\
\hline \multirow{3}{*}{$\begin{array}{l}\text { Wujud } \\
\text { fisik }\end{array}$} & $\begin{array}{l}\text { 1.Ruang tunggu pelayanan kantor ACT bersih dan } \\
\text { nyaman }\end{array}$ & 33 & 68 & 3 & 0 & 0 \\
\hline & $\begin{array}{l}\text { 2.Ketersediaan peralatan untuk mendukung kegiatan } \\
\text { sosial Ambulance peralatan medis dan peralatan } \\
\text { penyelamatan }\end{array}$ & 38 & 57 & 9 & 0 & 0 \\
\hline & $\begin{array}{l}\text { 3.ketersediaan fasilitas pendukung (tempat } \\
\text { ibadah,kantin dan ATM) }\end{array}$ & 49 & 53 & 2 & 0 & 0 \\
\hline \multirow{3}{*}{ Keandalan } & $\begin{array}{l}\text { 4.kecepatan dan kemudahan prosedur pelayanan yang } \\
\text { diberikan }\end{array}$ & 42 & 62 & 0 & 0 & 0 \\
\hline & S.keakuratan pencatatan/administrasi donatur & 40 & 52 & 12 & 0 & 0 \\
\hline & $\begin{array}{l}\text { 6.ketepatan penjelasaninformasiyang diberikan } \\
\text { karyav1an }\end{array}$ & 24 & 71 & 9 & 0 & 0 \\
\hline \multirow{3}{*}{$\begin{array}{l}\text { Daya } \\
\text { Tanggap }\end{array}$} & $\begin{array}{l}\text { 7.Komplain dari donatur langsung dttangani oleh } \\
\text { karyawan dengan cepat dan baik }\end{array}$ & 31 & 71 & 2 & 0 & 0 \\
\hline & $\begin{array}{l}\text { 8. karyawan segera memberikan bantuan bila ada } \\
\text { kesulitan pada donatur }\end{array}$ & $3 S$ & 67 & 2 & 0 & 0 \\
\hline & 9.karyawan mudah dihubungi oleh donatur & 26 & 67 & 9 & 0 & 0 \\
\hline \multirow{3}{*}{ Jaminan } & $\begin{array}{l}\text { 10. Keramahan dan kesopanan karyawan menimbulkan } \\
\text { rasa aman dan percava }\end{array}$ & 37 & 65 & 2 & 0 & 0 \\
\hline & $\begin{array}{l}\text { 11.ACT merupakanlembaga profesionaldalam } \\
\text { mendistribusikan } \\
\text { bantuan kenada penerima manfaat }\end{array}$ & 42 & 62 & 0 & 0 & 0 \\
\hline & $\begin{array}{l}\text { 12. karyawan dan relawan ACT ahlidan terampildalam } \\
\text { membantu penyelamatan dan pemulihan para korban } \\
\text { bencana }\end{array}$ & 34 & 63 & 7 & 0 & 0 \\
\hline \multirow{3}{*}{ Empati } & $\begin{array}{l}\text { 13. Pelayanan kepada semua donatur tanpa memandang } \\
\text { status } \\
\text { sosial dan lain-lain }\end{array}$ & 42 & 60 & 2 & 0 & 0 \\
\hline & $\begin{array}{l}\text { 14. karyawan melayani donatur dengan baik dan } \\
\text { memuaskan }\end{array}$ & 27 & 70 & 7 & 0 & 0 \\
\hline & $\begin{array}{l}\text { 15. Ketersedian dan kecukupan waktu bagi donatur } \\
\text { untuk berkonsultasi }\end{array}$ & 26 & 76 & 2 & 0 & 0 \\
\hline \multicolumn{2}{|l|}{ Bobot Skor } & $(5)$ & $(4)$ & $(3)$ & $(2)$ & $(1)$ \\
\hline \multicolumn{2}{|c|}{ Persentase $(\%)$} & 33,72 & 61,79 & 4,36 & 0 & 0 \\
\hline
\end{tabular}

Sumber : Data Priemer Diolah

Dari tabel diatas 11 hasil perhitungan kuesioner di dapat 33,72\% responden menyatakan sangat puas, $61,79 \%$ responden menyatakan puas, $4,29 \%$ responden menyatakan ragu, $0 \%$ responden menyatakan tidak puas dan $0 \%$ responden menyatakan sangat tidak puas. 
Pri Panjaningsih

5. Perspektif Proses Bisnis Internal

a. Pengukuran Proses Inovasi

Proses Inovasi $=\underline{\text { Jumlah Pendatapan jasa/program baru }} \times 100 \%$

Target Inovasi

Tabel 12 Rasio proses inovasi

\begin{tabular}{cccc}
\hline Tahun & $\begin{array}{c}\text { Jumlah pendapatan } \\
\text { program baru }\end{array}$ & Target Inovasi & Proses Inovasi \\
\hline 2016 & 3.586 .158 .830 & 5.000 .000 .000 & $71,72 \%$ \\
\hline 2017 & 28.759 .277 .593 & 35.000 .000 .000 & $82,16 \%$ \\
\hline 2018 & 60.443 .880 .493 & 70.000 .000 .000 & $86,34 \%$ \\
\hline
\end{tabular}

Sumber : Data Donatur Aksi Cepat Tangap

Tabel 12 menunjukkan bahwa Aksi Cepat Tanggap pada tahun 20162018 selalu mmegalami peningkatan proses inovasi.

b. Pengukuran Proses Operasi masing-masing program, dengan rumus sebagai berikut:

Proses Operasi $=\underline{\text { Realisasi perolehan masing-masing program } \times 100 \%}$

Target perolehan program

Tabel 13 Pengukuran jumlah peningkatan operasi masing-masing program

\begin{tabular}{lccc}
\hline & \multicolumn{3}{c}{ Rasio } \\
\cline { 2 - 4 } \multicolumn{1}{c}{ Program } & $\mathbf{2 0 1 6}$ & $\mathbf{2 0 1 7}$ & $\mathbf{2 0 1 8}$ \\
\hline Program kemanusiaan & $91 \%$ & $157 \%$ & $110 \%$ \\
\hline Program Qurban & $58 \%$ & $56 \%$ & $67 \%$ \\
\hline Program Wakaf & $40 \%$ & $29 \%$ & $34 \%$ \\
\hline Program Wakaf & $75 \%$ & $70 \%$ & $45 \%$ \\
\hline
\end{tabular}

Sumber : Data Donatur Aksi Cepat Tangap

Tabel 13 menunjukkan bahwa program kemanusiaan merupakan program yang memiliki rasio operasi yang paling tinggi diantara ketiga program lainnya. 
6. Analisis kinerja proses bisnis dan internal

Tabel 14 Hasil Kuesioner Proses Bisnis dan Internal

\begin{tabular}{|c|c|c|c|c|c|c|}
\hline \multirow{2}{*}{ lndikator } & \multirow{2}{*}{$\begin{array}{c}\text { Pemyataan } \\
\text { Kuesioner } \\
\end{array}$} & \multicolumn{5}{|c|}{ Jumlah Responden } \\
\hline & & SS & $\mathrm{S}$ & $\mathrm{R}$ & TS & STS \\
\hline \multirow{3}{*}{$\begin{array}{c}\text { Sarana dan } \\
\text { Prasarana }\end{array}$} & $\begin{array}{l}\text { 1.Tersedia prasarana sesuai kebutuhan dan } \\
\text { dalam kondisi baik 'Peralatan dan } \\
\text { perlengkapan, printer, komputer, mesin foto } \\
\text { kopi, }\end{array}$ & 120 & 95 & 3 & 0 & 0 \\
\hline & $\begin{array}{l}\text { 2. Komputerisasi telah berjalan dengan baik } \\
\text { dalam menunjang efisiensi dan efektivitas } \\
\text { bekerja }\end{array}$ & 68 & 130 & 17 & 3 & 0 \\
\hline & $\begin{array}{l}\text { 3. Data dan informasi yang dibutuhkan } \\
\text { dalam mendukung pekerjaan dapat diperoleh } \\
\text { dengan mudah dan lengkap }\end{array}$ & 56 & 142 & 10 & 6 & 4 \\
\hline \multirow{3}{*}{ Proses } & $\begin{array}{l}\text { 4.Target dan waktu penyelesaian pekerjaan } \\
\text { sesuai dengan kemampuan karyawan }\end{array}$ & 56 & 125 & 22 & 15 & 0 \\
\hline & $\begin{array}{l}\text { 5. karyawan mampu mengatasi hambatan } \\
\text { dalam pekerjaan dengan baik }\end{array}$ & 23 & 174 & 14 & 7 & 0 \\
\hline & $\begin{array}{l}\text { 6.karyawan mampu memberikan pelayanan } \\
\text { sesuai dengan prosedur vane sudah ada }\end{array}$ & 22 & 175 & 14 & 7 & 0 \\
\hline \multirow{3}{*}{ Kualitas } & $\begin{array}{l}\text { 7.karyawan yang bekerja diACT memiliki } \\
\text { kemapuan sesuai kebutuhan }\end{array}$ & 38 & 160 & 14 & 6 & 0 \\
\hline & $\begin{array}{l}\text { 8.Semua karyawan diACT mempunyai } \\
\text { keterampilan yang kompeten sesuai bidang } \\
\text { pekerjaannva. }\end{array}$ & 23 & 167 & 21 & 7 & 4 \\
\hline & $\begin{array}{l}\text { 9.Tingkat kesalahan yang dilakukan } \\
\text { karyawan dalam pekerjaannya rendah }\end{array}$ & 0 & 190 & 21 & 7 & 0 \\
\hline \multicolumn{2}{|l|}{ Bobot Skor } & $(5)$ & $(4)$ & (3) & $(2)$ & $(1)$ \\
\hline \multicolumn{2}{|c|}{ Persentase (\%) } & 20,69 & 69,22 & 6,93 & 2,96 & 0,41 \\
\hline
\end{tabular}

Sumber : Data Priemer Diolah

Dari Tabel 14 hasil perhitungan kuesioner di dapat 20,69\% responden menyatakan sangat setuju, 69,22 \% responden menyatakan setuju, 6,93\% responden menyatakan ragu, $2,96 \%$ responden menyatakan tidak setuju dan $0,41 \%$ responden menyatakan sangat tidak setuju.

7. Persepektif Pembelajaran dan Pertumbuhan

Perspektif pertumbuhan dan pembelajaran memberikan penilaian yang merupakan pemacu untuk membangun kualitas pelayanan dan kualitas personel yang diperlukan untuk mewujudkan target keuangan, pelanggan dan proses internal. Tolok ukur yang digunakan adalah peningkatan kapabilitas karyawan dan peningkatan komitmen karyawan.

a. Retensi Karyawan

Penilaian dilakukan untuk menilai tingkat komitmen karyawan yang dapat dinilai dari tingkat retensi karyawan. Tingkat retensi karyawan dinilai baik apabila selama periode pengamatan mengalami penurunan, dinilai sedang apabila fluktuatif dan dinilai kurang apabila mengalami peningkatan. Retensi karyawan $=\underline{\text { Jumlah karyawan keluar per periode } \mathrm{x} 100 \%}$

Jumlah total karyawan 
Tabel 15 Pengukuran retensi karyawan

\begin{tabular}{cccc}
\hline Tahun & $\begin{array}{c}\text { Jumlah karyawan } \\
\text { keluar }\end{array}$ & Total karyawan & $\begin{array}{c}\text { Retensi } \\
\text { karyawan }\end{array}$ \\
\hline 2016 & 39 & 195 & $20 \%$ \\
\hline 2017 & 53 & 295 & $17,96 \%$ \\
\hline 2018 & 59 & 421 & $14,01 \%$ \\
\hline
\end{tabular}

Sumber : Data Yayasan Aksi Cepat Tanggap

Tabel 15 menunjukkan bahwa tingkat retensi karyawan Aksi Cepat Tanggap dari tahun ketahun menurun yakni pada tahun 2016 sebesar 20\%, tahun 2017 sebesar 17,96 \% tahun 2018 sebesar 14,01\%. Dengan demikian tingkat retensi karyawan Aksi cepat tanggap dikategorikan "baik".

b. Produktivitas karyawan

Pengukuran produktivitas karyawan ditunjukkan melalui perbandingan antara pendapatan yang diperoleh Yayasan Aksi Cepat Tanggap dalam satu tahun dengan total karyawan pada tahun tersebut. Peningkatan produktivitas karyawan menunjukkan kinerja karyawan Aksi Cepat Tanggap semakin baik

Produktivitas Karyawan $=\quad$ Penerimaan donasi

Jumlah total karyawan

Tabel 16 Pengukuran produktivitas karyawan

Tahun Penerimaan Donasi $\begin{gathered}\text { Jumlah total } \\ \text { karyawan }\end{gathered} \begin{gathered}\begin{array}{c}\text { Produktivitas } \\ \text { Karyawan (dalam } \\ \text { Rupiah) }\end{array}\end{gathered}$

\begin{tabular}{cccc}
\hline 2016 & 146.000 .000 .000 & 195 & 748.717 .948 \\
\hline 2017 & 308.000 .000 .000 & 295 & 1.044 .067 .796 \\
\hline 2018 & 616.000 .000 .000 & 421 & 1.463 .182 .897 \\
\hline
\end{tabular}

Sumber : Data sekunder telah diolah

Berdasarkan Tabel 16 didapatkan gambaran bahwa tingkat produktivitas karyawan Aksi Cepat Tanggap mengalami peningkatan sejak tahun 2016 sampai tahun 2018. Peningkatan produktivitas karyawan menggambarkan kinerja dalam aspek produktivitas karyawan tergolong baik. Hal yang menyebabkan peningkatan produktivitas karyawan adalah jumlah pendapatan yang diperoleh selama tahun 2012 sampai tahun 2014 mengalami peningkatan.

c. Peningkatan kepuasan karyawan

Peningkatan kapabilitas karyawan dinilai dari peningkatan pelatihan/ seminar yang diadakan baik dari dalam maupun luar rumah sakit. Tingkat pelatihan karyawan dinilai baik apabila mengalami peningkatan, dinilai sedang apabila fluktuatif dan dinilai kurang apabila mengalami penurunan selama periode penelitian. 
Analisis Perspektif Keuangan, Pelanggan, Proses Bisnis dan Pertumbuhan dapat Menilai Kinerja Organisasi

8. Analisis perspektif pertumbuhan dan pembelajaran.

Tabel 17 Hasil kuesioner kepuasan karyawan

\begin{tabular}{|c|c|c|c|c|c|c|}
\hline \multirow{2}{*}{ Indikator } & \multirow{2}{*}{$\begin{array}{c}\text { Pernyataan } \\
\text { Kuesioner }\end{array}$} & \multicolumn{5}{|c|}{ Jumlah responden } \\
\hline & & SS & $S$ & $\mathrm{R}$ & TS & STS \\
\hline \multirow{2}{*}{ Motivasi } & $\begin{array}{l}\text { 1.ACT Selalu memberikan motivasi kepada } \\
\text { karyawannya untuk bekerja lebih baik dari } \\
\text { sebelumnya }\end{array}$ & 108 & $\begin{array}{c}10 \\
1\end{array}$ & 3 & 6 & 0 \\
\hline & $\begin{array}{l}\text { 2.Tersedia program kompensasi yang } \\
\text { menunjang apresiasi terhadap karyawan } \\
\text { berprestasi }\end{array}$ & 80 & 124 & 11 & 3 & 0 \\
\hline \multirow{2}{*}{$\begin{array}{l}\text { Kesempatan } \\
\text { mengembankan } \\
\text { diri }\end{array}$} & $\begin{array}{l}\text { 3.ACT melakukan peningkatan kinerja } \\
\text { karyawan dengan pelatihan dan pendidikan }\end{array}$ & 115 & 81 & 14 & 8 & 0 \\
\hline & $\begin{array}{l}\text { 4.ACT rutin mengadakan seminar untuk } \\
\text { meningkatkan kualitas sumber daya } \\
\text { karyawan }\end{array}$ & 80 & 118 & 13 & 3 & 4 \\
\hline \multirow{2}{*}{ Inovasi } & $\begin{array}{l}\text { 5.ACT mempunyai program kompetisi ide } \\
\text { dan saran untuk menciptakan inovasi-inovasi } \\
\text { baru }\end{array}$ & 56 & 111 & 36 & 15 & 0 \\
\hline & $\begin{array}{l}\text { 6.ACT menanamkan budaya kolaborasi } \\
\text { antar departmen atau dengan mitra untuk } \\
\text { meninakatkan kreativitas karvawan }\end{array}$ & 53 & 135 & 26 & 4 & 0 \\
\hline \multirow[b]{2}{*}{ Susasana } & $\begin{array}{l}\text { 7.Karyawan merasa nyaman bekerja } \\
\text { dilingkungan ACT }\end{array}$ & 76 & 121 & 21 & 0 & 0 \\
\hline & $\begin{array}{l}\text { 8.Fasilitas yang disediakan ACT sudah } \\
\text { menunjang pekerjaan setiap bekerja } \\
\text { karyawan }\end{array}$ & 59 & 159 & 0 & 0 & 0 \\
\hline Bobot Skor & & $(5)$ & (4) & (3) & $(2)$ & (1) \\
\hline Persentase $(\%)$ & & 35,95 & $\begin{array}{l}54, \\
47\end{array}$ & 7,11 & 2,24 & 0,23 \\
\hline
\end{tabular}

Sumber : Data Priemer Diolah

Dari Tabel 17 hasil perhitungan kuesioner perspektif pertumbuhan dan pembelajaran di dapat 35,95\% responden menyatakan sangat setuju, 54,47\% responden menyatakan setuju, 7,11\% responden menyatakan ragu, 2,24\% responden menyatakan tidak setuju dan $0,23 \%$ responden menyatakan sangat tidak setuju. Mayoritas responden menyatakan setuju dan kurang dari 10\% responden yang menyatakan ragu dan tidak setuju.

\section{B. Pembahasan}

Pengukuran kinerja menurut Mulyadi (2011) dengan menggunakan metode Balanced Scorecard yang terdiri dari 4 perspektif diantaranya: persfektif keuangan, perspektif pelanggan, perspektif bisnis dan internal dan perspektif pembelajaran dan pertumbuhan.

Dalam perspektif keuangan semakin tinggi rasio efisiensi maka semakin baik pula kualitas dan kuantitas organisasi dalam memenuhi target input (penerimaan donasi) dan output (program atau produk). Dari Tabel 8 terjadi penurunan rasio efektivitas ditahun 2018 yakni sebesar 9,72\% (102,70\%-92,98\%) dibandingkan 
tahun 2017. Hal tersebut disebabkan karna lembaga hanya mampu mencapai perolehan donasi 92,98\% dari target yang telah ditetapkan.

Meskipun demikian tahun 2018 terjadi peningkatan perolehan donasi sebesar 50\% atau senilai $\mathrm{Rp}$ 308.000.000.000 (Rp 616.000.000.000-308.000.000.000) hal tersebut disebakan pada tahun 2018 terjadi bencana alam yakni gempa Lombok. Dengan demikian untuk perspektif keuangan rasio efektivitas dikategorikan "Baik"

Perspektif pelanggan atau donatur yang terdiri dari akuisisi donatur, retensi donatur dan kepuasan donatur. Dalam rasio akuisisi donatur pada tahun 2018 mengalami penurunan 4,39\% (31,33\%-26,94\%) dibandingkan dengan tahun 2017 . Artinya pada tahun 2018 mayoritas donatur yang berdonasi adalah donatur tetap. Hal tersebut disebabkan donatur yang berdonasi adalah donatur dari lembaga/perusahaan yang sudah pernah bekerja sama, meskipun demikian ditahun 2018 donatur baru bertambah 15,03 \% atau sejumlah 12.163 donatur dengan demikian kemampuan ACT dalam mengakuisisi donatur dikategorikan "Baik"

Donatur merupakan ujung tombak lembaga dalam menjalankan kegiatan operasional lembaga karnanya lembaga harus mampu menjaga hubungan baik dengan donatur. Dalam rasio retensi donatur pada Tabel 10 terjadi penurunan rasio retensi donatur dari tahun ketahun. Khususnya pada tahun 2018 terjadi penurunan rasio retensi donatur sbesar $15,18 \%(42,11 \%-26,93 \%)$ semakin rendah rasio retensi donatur menunjukkan belum maksimalnya lembaga dalam mempertahankan donatur. Karnanya dalam hal kemampuan mempertahankan donatur sudah dikategorikan "Cukup Baik".

Dalam perspektif kepuasan donatur tingkat kepuasan donatur terhadap pelayanan sesuai dengan Tabel 11 menjelaskan bahwa hanya 33,72\% yang menyatakan sangat puas hal tersebut disebabkan sedikitnya responden yang merasa sangat puas terhadap ketepatan penjelasan informasi yang diberikan karyawan lembaga. Serta reponden menyatakan puas yakni $61,79 \%$ hal tersebut karna donatur merasa diberikan kecukupan waktu untuk berkonsultasi dengan karyawan. Dalam perspekif kepuasan pelanggan sudah dapat dikategorikan "Baik".

Dalam perspektif proses inovasi terjadi kenaikan dari tahun ketahun. Pada tahun 2018 inovasi mencapai 86,34\% karna pada tahun tersebut diluncurkan program-program baru sejumlah 20 program. Program yang banyak menghimpun donasi adalah program SKDI kapal kemanusiaan karna pada tahun tersebut terjadi konflik di Palestina sehingga lembaga mampu mencapai target perolehan donasi (program baru). Dalam hal ini proses inovasi dikategorikan "Baik"

Untuk mengetahui peningkatan donasi dimasing-masing program maka perlu dianalisis proses operasi masing-masing program. sesuai dengan tabel 15 program yang memiliki operasi dengan rasio tertinggi di tahun 2018 adalah program kemanusiaan yang mencapai $110 \%$ hal tersebut disebabkan Indonesia merupakan negara yang berada di cincin api dunia yang mempunyai potensi besar terjadi bencana seperti gempa, tsunami, banjir, longsor dan lain-lain. Hal tersebut menjadi salah satu penyebab donasi kemanusiaan memegang proses operasi tertinggi. 
Sedangkan program yang memiliki rasio operasi yang rendah adalah program wakaf yakni hanya 34\% hal tersebut disebabkan karna program-program wakaf adalah program jangka panjang dan kurang begitu diminati oleh para donatur. Sehingga rasio dari keempat program di tahun 2018 yakni program kemanusiaan $110 \%$, program Qurban $67 \%$, program Wakaf $34 \%$ dan program Zakat $45 \%$ memperoleh rata-rata rasio proses operasi $64 \%$ karnanya untuk proses operasi dikategorikan "Cukup Baik"

Pengukuran proses internal, sarana prasarana dalam perspektif proses bisnis dan internal sesuai dengan Tabel 16 menjelaskan bahwa hanya 20,69\% yang menyatakan sangat puas hal tersebut disebabkan sedikitnya responden yang merasa sangat puas terhadap rendahnya tingkat kesalahan yang dilakukan karyawan dalam bekerja. Serta reponden menyatakan puas yakni 69,22\% hal tersebut karna karyawan mampu memberikan pelayanan sesuai dengan prosedur yang sudah ada. Dalam perspekif proses bisnis dan internal sudah dapat dikategorikan "Baik".

Karyawan merupakan asset lembaga yang harus terus dikembangkan dan ditingkatkan skill dan kapabilitasnya. Perspektif Pembelajaran dan pertumbuhan mengenai retensi karyawan ditahun 2018 mengalami penurunan yakni 3,95\% 17,96\%-14,01\%) dari tahun 2017. Artinya lembaga mampu mempertahankan karyawan sebagai asset lembaga.

Kemapuan lembaga dalam menyediakan fasilitas yang menunjang setiap karyawan merupakan salah satu indikator yang paling banyak disetujui oleh responden (karyawan). Dalam hal retensi karyawan dikategorikan sudah "baik"

Pengukuran produktivitas karyawan pada dasarnya digunakan untuk mengetahui sejauh mana tingkat efektivitas dan efisiensi kerja karyawan dalam menghasilkan suatu hasil. Rasio produktivitas karyawan Aksi Cepat Tanggap di tahun 2018 mengalami peningkatan sejumlah Rp 419.115.101 (1.0463.182.897 1.044.067.796) dibandingkan dengan tahun 2017. Artinya karyawan lembaga sudah maksimal dalam tingkat efektivitas dan efisiensi dalam bekerja. Karnanya dalam produktivitas karyawan dikategorikan "baik"

Kepuasan karyawan dalam bekerja dapat mendorong tingkat produktivitas karyawan dalam bekerja. Dalam perspektif proses pertumbuhan dan pembelajaran tingkat kepuasan karyawan sesuai dengan Tabel 17 menjelaskan bahwa hanya $35,95 \%$ yang menyatakan sangat puas hal tersebut disebabkan sedikitnya responden yang setuju terhadap budaya kolaborasi antar departemen.. Serta reponden menyatakan puas yakni $54,47 \%$ hal tersebut karna fasilitas yang disediakan lembaga sudah menunjang pekerjaan setiap karyawan. Dalam perspekif kepuasan karyawan perspektif pertumbuhan dan pembelajaran sudah dapat dikategorikan "Baik".

Berikut disajikan tabel yang merangkum hasil dari kinerja secara keseluruhan pada empat perspektif Balanced Scorecard dengan standar yang ditetapkan. 
Pri Panjaningsih

Tabel 18 Hasil Ukuran Kinerja

\begin{tabular}{|c|c|c|c|c|}
\hline Perspektif & Sasaran Strategik & Ukuran & Kategori & Skor \\
\hline Keuangan & Rasio efektivitas & $\begin{array}{l}\text { Peningkatan } \\
\text { efisiensi } \\
\text { keuangan }\end{array}$ & Baik & 1 \\
\hline \multirow{3}{*}{ Pelanggan } & \multirow{3}{*}{$\begin{array}{l}\text { Meningkatnya } \\
\text { kepercayaan donatur }\end{array}$} & $\begin{array}{l}\begin{array}{l}\text { Akuisisi } \\
\text { donatur }\end{array} \\
\end{array}$ & Baik & 1 \\
\hline & & $\begin{array}{l}\text { Retensi } \\
\text { donatur }\end{array}$ & Cukup & 0 \\
\hline & & $\begin{array}{l}\text { Kepuasan } \\
\text { donatur }\end{array}$ & Baik & 1 \\
\hline \multirow{3}{*}{ Bisnis } & \multirow{3}{*}{$\begin{array}{l}\text { Meningkatnya proses } \\
\text { layanan kepada donatur }\end{array}$} & $\begin{array}{l}\text { Peningkatan } \\
\text { Inovasi }\end{array}$ & Baik & 1 \\
\hline & & $\begin{array}{l}\text { Peningkatan } \\
\text { Operasi }\end{array}$ & Cukup & 0 \\
\hline & & $\begin{array}{l}\text { Peningkatan } \\
\text { proses bisnis \& } \\
\text { internal }\end{array}$ & Baik & 1 \\
\hline \multirow{3}{*}{$\begin{array}{l}\text { Pembelajaran } \\
\text { dan } \\
\text { Pertumbuhan }\end{array}$} & \multirow{3}{*}{$\begin{array}{l}\text { Meningkatnya } \\
\text { kapabilitas karyawan, } \\
\text { Meningkatnya } \\
\text { komitmen karyawan }\end{array}$} & $\begin{array}{l}\text { Retensi } \\
\text { Karyawan }\end{array}$ & Baik & 1 \\
\hline & & $\begin{array}{l}\text { produktivitas } \\
\text { Karyawan }\end{array}$ & Baik & 1 \\
\hline & & $\begin{array}{l}\text { Kepuasan } \\
\text { karyawan }\end{array}$ & Baik & 1 \\
\hline Total Skor & & & Baik & 8 \\
\hline
\end{tabular}

Sumber: (Mulyadi, 2011)

Dari empat perspektif Balanced Scorecard yang digunakan dengan 10 ukuran kinerja, ada 8 ukuran yang mencapai standar yang telah ditetapkan, dan hanya 2 ukuran yang belum mancapai standar yakni kemampuaan retensi donatur dan proses operasi dari tahun ketahun mengalami penurunan. Dengan demikian hasil pengukuran kinerja dengan metode Balanced Scorecard dikategorikan "Baik".

Berdasarkan penelitian yang telah dilakukan melalui data-data yang telah dikumpulkan serta berdasarkan model penelitian maka disimpulkan $\mathrm{H} 1$ perspektif keuangan, pelanggan, bisnis internal dan pertumbuhan pembelajaran dapat menilai kinerja organisasi.

\section{Kesimpulan}

Dari perspektif ini secara umum kinerja keuangan Yayasan Aksi Cepat Tanggap bisa dikatakan baik sebab di tahun 2018 terjadi peningkatan donasi sebesar 50\% atau senilai Rp 308.000.000.000.

Kinerja Yayasan Aksi Cepat Tanggap dilihat dari perspektif Pelanggan (donatur) dengan indikator kepuasan konsumen. Secara keseluruhan dapat dikatakan baik. Dimana secara keseluruhan mayoritas hasil jawaban responden menunjukkan persentase 
diatas $90 \%$. Dengan begitu berarti rata-rata hampir seluruh donatur merasa nyaman dan puas terhadap fasilitas dan pelayanan yang diberikan Yayasan Aksi Cepat Tanggap.

Kinerja Yayasan Aksi Cepat Tanggap dilihat dari perspektif proses bisnis internal dilihat dari indikator proses operasi, inovasi dan proses bisnis internal telah mencapai standar ideal. Proses Inovasi mencapai 86,34\% ditahun 2018, dan rasio operasi yang tertinggi adalah program kemanusiaan yang mencapai $110 \%$ dan program wakaf hanya mencapaik 34\%.

Pengukuran proses internal dengan indikator ketersediaan sarana dan prasarana responden menyatakan puas yakni 89,91\%.

Kinerja Yayasan Aksi Cepat Tanggap dilihat dari perspektif pertumbuhan dan pembelajaran dengan indikator retensi karyawan, produktivitas karyawan dan kepuasan karyawan. Rasio retensi karyawan tahun 2018 mengalami penurunan 3,95\% hal tersebut membuktikan yayasan dapat mempertahankan karyawan dengan baik. Rasio produktivitas karyawan di tahun 2018 mengalami pengingkatan sejumlah Rp 419.115.101,--

Hasil responden pada perspektif kepuasan karyawan yakni sebesar 90,42\% responden menyatakan puas. 
Pri Panjaningsih

\section{BIBLIOGRAFI}

Alimudin, Arasy. (2017). Analisis Pencapaian Strategi Menggunakan Balanced Scorecard. Jurnal Pendidikan Ekonomi Dan Bisnis (JPEB), 5(2), 194-205.

Aulia, Dewi, \& Ikhwana, Andri. (2012). Perencanaan strategi pengembangan usaha kain tenun sutra dengan pendekatan metode balanced scorecard (Studi kasus di Pabrik Sutra Tiga Putra). Jurnal Kalibrasi, 10(1).

Fitriyani, Dewi. (2014). Balanced Scorecard: Alternatif Pengukuran Kinerja Organisasi Sektor Publik. Jurnal Cakrawala Akuntansi ISSN, 1979, 4851.

Ghozali, Imam, \& Latan, Hengky. (2015). Partial Least Squares, konsep, teknik dan aplikasi menggunakan program Smartpls 3.0 untuk penelitian empiris. Semarang: Badan Penerbit UNDIP.

Hadiyati, Nuniek. (2014). Pengukuran Kinerja Dengan Metode Balanced Scorecard (Studi Empiris Pada Rumah Sakit PKU Muhammadiyah Delanggu Klaten). Universitas Muhammadiyah Surakarta.

Mulyadi. (2011). Auditing (Edisi keen). Jakarta: Salemba Empat.

Nurhayati, Mega Ayu. (2018). Pengaruh Promosi Terhadap Keputusan Konsumen Memilih Jasa Cuci Steam Maju Abadi Cuci Steam Desa Lemahputih Kecamatan Lemahsugih Kabupaten Majalengka. Syntax Literate; Jurnal Ilmiah Indonesia, $3(2), 47-57$.

Pramadhany, Wahyu Eko Yuzandra, \& Rahardjo, Shiddiq Nur. (2011). Penerapan Metode Balanced Scorecard Sebagai Tolok Ukur Penilaian Kinerja Pada Organisasi Nirlaba (Studi Kasus Pada Rumah Sakit Bhayangkara Semarang). Universitas Diponegoro.

Radithya, Edwin, \& Tin, Se. (2011). Evaluasi Penerapan Balance Scorecard Terhadap Efisiensi Kinerja Karyawan di Divisi Penjualan PT. AUTO 2000. Akurat Jurnal Ilmiah Akuntansi, 2(06).

Setianto, Anang Wahyu Eko. (2020). Hukum Tentang Penarikan Uang Kembalian Untuk Program Donasi. AL-IQTISHADY: Jurnal Ekonomi Syariah, 1(1), 17-32.

Wijaya, Novia. (2012). Pengaruh Intellectual Capital terhadap kinerja keuangan dan nilai pasar perusahaan perbankan dengan metode Value Added Intellectual Coefficient. Jurnal Bisnis Dan Akuntansi, 14(3), 157-180. 